\title{
Front Matter: Volume 8973
}

, "Front Matter: Volume 8973," Proc. SPIE 8973, Micromachining and Microfabrication Process Technology XIX, 897301 (27 March 2014); doi: $10.1117 / 12.2064078$

SPIE. Event: SPIE MOEMS-MEMS, 2014, San Francisco, California, United States 


\title{
PROCEEDINGS OF SPIE
}

\section{Micromachining and Microfabrication Process Technology XIX}

\author{
Mary Ann Maher \\ Paul J. Resnick \\ Editors
}

\section{4-6 February 2014 \\ San Francisco, California, United States}

Sponsored by

SPIE

Cosponsored by

Samsung Advanced Institute of Technology (Korea, Republic of)

Published by

SPIE 
The papers included in this volume were part of the technical conference cited on the cover and title page. Papers were selected and subject to review by the editors and conference program committee. Some conference presentations may not be available for publication. The papers published in these proceedings reflect the work and thoughts of the authors and are published herein as submitted. The publisher is not responsible for the validity of the information or for any outcomes resulting from reliance thereon.

Please use the following format to cite material from this book:

Author(s), "Title of Paper," in Micromachining and Microfabrication Process Technology XIX, edited by Mary Ann Maher, Paul J. Resnick, Proceedings of SPIE Vol. 8973 (SPIE, Bellingham, WA, 2014) Article CID Number.

ISSN: 0277-786X

ISBN: 9780819498861

Published by

SPIE

P.O. Box 10, Bellingham, Washington 98227-0010 USA

Telephone +1 3606763290 (Pacific Time) · Fax +1 3606471445

SPIE.org

Copyright @ 2014, Society of Photo-Optical Instrumentation Engineers.

Copying of material in this book for internal or personal use, or for the internal or personal use of specific clients, beyond the fair use provisions granted by the U.S. Copyright Law is authorized by SPIE subject to payment of copying fees. The Transactional Reporting Service base fee for this volume is $\$ 18.00$ per article (or portion thereof), which should be paid directly to the Copyright Clearance Center (CCC), 222 Rosewood Drive, Danvers, MA 01923. Payment may also be made electronically through CCC Online at copyright.com. Other copying for republication, resale, advertising or promotion, or any form of systematic or multiple reproduction of any material in this book is prohibited except with permission in writing from the publisher. The CCC fee code is 0277-786X/14/\$18.00.

Printed in the United States of America.

Publication of record for individual papers is online in the SPIE Digital Library.

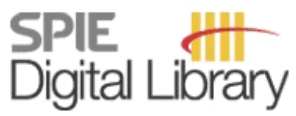

SPIEDigitalLibrary.org

Paper Numbering: Proceedings of SPIE follow an e-First publication model, with papers published first online and then in print and on CD-ROM. Papers are published as they are submitted and meet publication criteria. A unique, consistent, permanent citation identifier (CID) number is assigned to each article at the time of the first publication. Utilization of CIDs allows articles to be fully citable as soon as they are published online, and connects the same identifier to all online, print, and electronic versions of the publication. SPIE uses a six-digit CID article numbering system in which:

- The first four digits correspond to the SPIE volume number.

- The last two digits indicate publication order within the volume using a Base 36 numbering

system employing both numerals and letters. These two-number sets start with 00, 01, 02, 03, 04, 05, 06, 07, 08, 09, 0A, 0B ... 0Z, followed by 10-1Z, 20-2Z, etc.

The CID Number appears on each page of the manuscript. The complete citation is used on the first page, and an abbreviated version on subsequent pages. Numbers in the index correspond to the last two digits of the six-digit CID Number. 


\section{Contents}

vii Conference Committee

\section{SESSION 1 DEVICE FABRICATION}

897302 Fabrication of microelectromechanical systems (MEMS) cantilevers for photoacoustic (PA) detection of terahertz $(\mathrm{THz})$ radiation [8973-1]

R. Newberry, N. Glauvitz, R. A. Coutu Jr., Air Force Institute of Technology (United States);

I. R. Medvedev, D. Petkie, Wright State Univ. (United States)

897304 Isolating the negative stiffness region of a buckled $\mathrm{Si} / \mathrm{SiO}_{2}$ membrane [8973-3]

K. K. Ziegler, R. A. Lake, R. A. Coutu Jr., Air Force Institute of Technology (United States)

897305 Thin film fabrication and system integration test run for a microactuator for a tuneable lens [8973-4]

D. Hoheisel, L. Rissing, Leibniz Univ. Hannover (Germany)

\section{SESSION 2 DEVICE DESIGN}

897307 Calibrating bimetallic grayscale photomasks to photoresist response for precise microoptics fabrication [8973-6]

G. H. Chapman, R. Qarehbaghi, S. Roche, Simon Fraser Univ. (Canada)

\section{SESSION 3 MICROFABRICATION TECHNIQUES}

897309 Deep silicon etching: current capabilities and future directions (Invited Paper) [8973-9] R. Westerman, L. Martinez, D. Pays-Volard, K. Mackenzie, T. Lazerand, Plasma-Therm LLC (United States)

8973 OA Chemical mechanical polishing of boron-doped polycrystalline silicon [8973-10] H. Pirayesh, K. Cadien, Univ. of Alberta (Canada)

8973 OB A novel process for the fabrication of microstructures half the listed minimum feature size of a direct-write laser lithography system [8973-11]

R. A. Lake, R. A. Coutu Jr., Air Force Institute of Technology (United States)

8973 OD Periodic nanostructures fabricated by Talbot extreme ultraviolet lithography [8973-13] W. Li, D. Patel, C. S. Menoni, Colorado State Univ. (United States); A. Stein, Brookhaven National Lab. (United States); W. Chao, E. Anderson, Lawrence Berkeley National Lab. (United States); M. C. Marconi, Colorado State Univ. (United States)

8973 OE Fabrication of 3D surface structures using grayscale lithography [8973-14]

C. Stilson, R. Pal, R. A. Coutu Jr., Air Force Institute of Technology (United States) 
8973 OF Residual stress control during the growth and release process in gold suspended microstructures [8973-15]

A. Sharma, D. Bansal, A. Kumar, CSIR-Central Electronics Engineering Research Institute (India); D. Kumar, Kurukshetra Univ. (India); K. Rangra, CSIR-Central Electronics Engineering Research Institute (India)

\section{SESSION 4 NEW MATERIALS FOR MICROFABRICATION}

8973 OG Phase Change Materials (PCM) fabricated in vertical structures for reconfigurable and tunable circuits [8973-16]

E. Barajas, R. A. Coutu Jr., Air Force Institute of Technology (United States)

$8973 \mathrm{OH} \quad$ Microfabrication of passive electronic components with printed graphene-oxide deposition [8973-17]

D. Sinar, G. K. Knopf, The Univ. of Western Ontario (Canada); S. Nikumb, National Research Council Canada (Canada)

8973 Ol Optimal microelectromechanical systems (MEMS) device for achieving high pyroelectric response of AIN [8973-18]

B. Kebede, R. A. Coutu Jr., Air Force Institute of Technology (United States); L. Starman, Air Force Research Lab. (United States)

8973 0J Fabrication technology to increase surface area of ionomer membrane material and its application towards high surface area electric double-layer capacitors [8973-19] A. A. Chang, J. N. Patel, C. Cordoba, B. Kaminska, K. Kavanagh, Simon Fraser Univ. (Canada)

\section{SESSION 5 LASER MICROMACHINING}

8973 OK Laser micromachining of oxygen reduced graphene-oxide films [8973-20]

D. Sinar, G. K. Knopf, The Univ. of Western Ontario (Canada); S. Nikumb, National Research Council Canada (Canada); A. Andrushchenko, The Univ. of Western Ontario (Canada)

$8973 \mathrm{OL} \quad$ Laser assisted and hermetic room temperature bonding based on direct bonding technology [8973-21]

J. Haneveld, P. Tijssen, J. Oonk, M. Olde Riekerink, H. Tigelaar, R. van'† Oever, M. Blom, Micronit Microfluidics BV (Netherlands)

8973 OM Design and fabrication of sub-wavelength annular apertures on fiber tip for femtosecond laser machining [8973-22]

Y.-C. Tung, M.-H. Chung, I.-H. Sung, C.-K. Lee, National Taiwan Univ. (Taiwan)

\section{POSTER SESSION}

8973 ON Design of active temperature compensated composite free-free beam MEMS resonators in a standard process [8973-23]

G. Xereas, V.P. Chodavarapu, McGill Univ. (Canada) 
897300 Design and fabrication of three-axis accelerometer sensor microsystem for wide temperature range applications using semi-custom process [8973-24]

A. Merdassi, Y. Wang, G. Xereas, V. P. Chodavarapu, McGill Univ. (Canada)

8973 OP Facile fabrication of nanogap electrodes for suspended graphene characterization using direct ion beam patterning [8973-25]

Z. J. Qi, A. T. C. Johnson, Univ. of Pennsylvania (United States)

$89730 Q \quad$ Resonator structures on AIN ceramics surface treated by laser radiation [8973-26]

P. E. Koziol, A. J. Antonczak, B. Stepak, P. A. Gorski, Wroclaw Univ. of Technology (Poland); M. Walczakowski, N. Palka, Military Univ. of Technology (Poland); K. M. Abramski, Wroclaw Univ. of Technology (Poland)

8973 OR Annular heating of optical fiber with a $\mathrm{CO}_{2}$ laser with reflective axicon elements [8973-27] W. Klimowych, AFL (United States)

8973 OS Compliant MEMS mechanism to extend resolution in Fourier transform spectroscopy [8973-28]

A. Sauceda-Carvajal, Univ. Autónoma de Ciudad Juárez (Mexico);

H. D. Kennedy-Cabrera, J. Hernández-Torres, A. L. Herrera-May, Univ. Veracruzana (Mexico); J. Mireles Jr., Univ. Autónoma de Ciudad Juárez (Mexico)

Author Index 
Proc. of SPIE Vol. $8973897301-6$

Downloaded From: https://www.spiedigitallibrary.org/conference-proceedings-of-spie on 26 Apr 2023 Terms of Use: https://www.spiedigitallibrary.org/terms-of-use 


\title{
Conference Committee
}

\author{
Symposium Chair
}

David L. Dickensheets, Montana State University (United States)

Symposium Co-chair

Holger Becker, microfluidic ChipShop GmbH (Germany)

\section{Conference Chairs}

Mary Ann Maher, SoftMEMS (United States)

Paul J. Resnick, Sandia National Laboratories (United States)

Conference Program Committee

Ronald A. Coutu Jr., Air Force Institute of Technology (United States)

David G. Lishan, Plasma-Therm LLC (United States)

Sanjay Krishna, The University of New Mexico (United States)

Tamal Mukherjee, Carnegie Mellon University (United States)

Metin Ozen, Ozen Engineering, Inc. (United States)

Yu-Chuan Su, National Tsing Hua University (Taiwan)

T. C. Yih, California State University, Long Beach (United States)

Session Chairs

1 Device Fabrication

Mary Ann Maher, SoftMEMS (United States)

2 Device Design

Paul J. Resnick, Sandia National Laboratories (United States)

3 Microfabrication Techniques

Mary Ann Maher, SoftMEMS (United States)

4 New Materials for Microfabrication

Paul J. Resnick, Sandia National Laboratories (United States)

5 Laser Micromachining

David G. Lishan, Plasma-Therm LLC (United States) 
Proc. of SPIE Vol. $8973897301-8$

Downloaded From: https://www.spiedigitallibrary.org/conference-proceedings-of-spie on 26 Apr 2023 Terms of Use: https://www.spiedigitallibrary.org/terms-of-use 